\title{
The Effects of Surgery on the Nitrogen Metabolism of Parenterally Fed Human Neonates
}

\author{
BARRY DUFFY ${ }^{1}$ AND PAUL PENCHARZ
}

\begin{abstract}
The Montreal Children's Hospital, Montreal, Quebec; The Research Institute, The Hospital for Sick Children, and the Departments of Paediatrics and Nutritional Sciences, The University of Toronto,
\end{abstract} Toronto, Ontario, Canada

\begin{abstract}
Nitrogen retention and rates of whole body amino nitrogen flux, protein synthesis, and breakdown were measured in 18 neonates during the $72 \mathrm{~h}$ immediately postsurgery. The infants were all intravenously fed with a crystalline amino acid source (Vamin), glucose, and Intralipid The infants were divided into two groups based on amino acid intake: either $2.3 \mathrm{SD} 0.4 \mathrm{~g}$ or $3.9 \mathrm{SD} 0.5 \mathrm{~g} / \mathrm{kg} /$ day. Nonprotein energy intakes were similar and averaged $81 \mathrm{kcal} / \mathrm{kg} /$ day. Group $A(n=11)$ retained $145 \mathrm{SD} 110$ $\mathrm{mg} \mathrm{N} / \mathrm{kg} /$ day, whilst group B $(n=7)$ retained 315 SD 93 $\mathrm{mg} \mathrm{N} / \mathrm{kg} / \mathrm{day}(p<0.001)$. There were no differences seen in flux, synthesis or breakdown. However, group B had significantly higher net protein synthesis rates (synthesisbreakdown) ( $p<0.01)$. The improved nitrogen utilization in group B was achieved principally by a reduction in endogenous protein breakdown. There were no differences between the two groups in urinary creatinine or 3-methylhistidine excretion. Since these two parameters reflect skeletal muscle turnover the differences between groups in nitrogen retention and turnover appear to be mediated through visceral protein (Pediatr Res 20: 32-35, 1986)
\end{abstract}

\section{Abbreviation}

$\mathbf{N}$, nitrogen

It has been known for many years that surgery results in an increased urinary urea excretion and often a negative $\mathrm{N}$ balance. Several investigators using isotopically labeled amino acids have shown that this "catabolic" loss of nitrogen appeared to be a consequence of a reduction in whole body protein synthesis rather than an increase in proten breakdown (1-3). Amino acids which are not used for synthesis are then degraded resulting in an increased urea formation and thus, an increase in urinary nitrogen excretion.

Human newborn infants have limited protein and energy reserves (4). We have previously shown that newborns have high rates of whole body protein turnover (5). We therefore decided to study the effects of surgery on the $N$ metabolism of human newborn infants. Since the earlier studies had suggested that the increased urinary $\mathrm{N}$ losses were a consequence of a reduction in

Received May 6, 1985; accepted August 19, 1985.

Author for correspondence and reprints: Paul B. Pencharz, M.B., Ph.D., FRCP(C), Head, Division of Clinical Nutrition, The Hospital for Sick Children, 555 University Avenue, Toronto, Ontario, Canada M5G 1 X8.

This study was supported in part by the Medical Research Council of Canada, Grant MT-5466, and a grant from Pharmacia, Dorval, Quebec. B.D. was supported by a fellowship from McGill University, The Research Institute, The Montreal Children's Hospital, Montreal, Quebec.

'Present address: The Prince of Wales Chi,dren's Hospital, High Street, Randwick 2031, New South Wales, Australia. whole body protein synthesis, we hypothesized that giving increased amounts of exogenous amino acids as precursor might reverse this process and improve net protein synthesis. We therefore studied neonates receiving either $2.5 \mathrm{~g}$ or $4.0 \mathrm{~g} / \mathrm{kg} / \mathrm{day}$ of amino acids immediately postoperatively.

\section{MATERIALS AND METHODS}

Eighteen newborn infants were studied in the Neonatal Intensive Care Unit of The Montreal Children's Hospital. The subjects were divided randomly into two groups on the basis of the level of amino acid received. The clinical characteristics of the two diet groups are shown in Table 1. All infants received amino acid/glucose solutions with complete mineral and vitamin additions similar to those we have previously reported (6). The amino acid source chosen was a crystalline amino acid mixture patterned on egg albumin (Vamin; Vitrum Co., Stockholm, Sweden). The amino acid glucose solutions were infused in combination with a $10 \%$ soy bean lipid emulsion (Intralipid; Vitrum Co.).

The studies were approved by the Human Experimentation Committee of The Montreal Children's Hospital and informed, written consent was obtained from the parents. The infants were randomly allocated to one of the two total parenteral nutrition regimes, either $2.5 \mathrm{~g}$ amino acid or $4 \mathrm{~g}$ amino acid $/ \mathrm{kg} /$ day. Parenteral nutrition was started within $24 \mathrm{~h}$ postoperatively. Seventy-two-hour $\mathrm{N}$ balance, whole body protein turnover, and urine 3-methylhistidine excretion studies were carried out also starting within $24 \mathrm{~h}$ after surgery. Our balance techniques have been previously described (7). All studies were performed with the neonate in a standard servocontrolled incubator. The surgical procedures the infants underwent are listed by diet group in Table 1.

Whole body $\mathrm{N}$ turnover was studied using the approach described by Picou and Taylor-Roberts (8) and modified by Pencharz et al (7). 15N-glycine, approximately 95 atoms \% enriched (Merck, Sharp and Dohme, Dorval, Quebec, Canada), was dissolved in distilled water and the resulting solution was sterilized by passage through a $0.22 \mu$ Millipore filter (Millipore Corp., Bedford, MA). The sterilized $15 \mathrm{~N}$-glycine solution was then put in single-dose vials. Each batch of vials was monitored for sterility and random vials were pyrogen-tested. The $15 \mathrm{~N}$-glycine was given intravenously every $3 \mathrm{~h}$ during the 72 -h balance turnover study in a dose of approximately $0.6 \mathrm{mg} 15 \mathrm{~N} / \mathrm{kg} /$ day. Urine was collected immediately before each $15 \mathrm{~N}$-glycine dose and at the end of the study for $15 \mathrm{~N}$-urea analysis. The enrichment of $15 \mathrm{~N}$ glycine was verified by mass spectroscopy.

Amino acid solutions, urine, nasogastric aspirates, ostomy drainage, and feces were analyzed for total nitrogen (9). Urine 3methylhistidine was measured using a Beckman 120 C amino acid analyzer (Beckman Instruments Inc., Palo Alto, CA). Urinary urea- $\mathrm{N}$ was isolated as previously described and its $15 \mathrm{~N}$ 
Table 1. Clinical characteristics and surgical procedures $(\text { mean } \pm S D)^{*}$

\begin{tabular}{|c|c|c|}
\hline & \multicolumn{2}{|c|}{ Diet group } \\
\hline & $\mathrm{A}$ & $\mathrm{B}$ \\
\hline \multicolumn{3}{|l|}{ Characteristic } \\
\hline$n$ & 11 & 7 \\
\hline Birth wt (g) & $2390 \pm 1021$ & $2045 \pm 958$ \\
\hline $\begin{array}{l}\text { Gestational age } \\
(w \mathrm{k})\end{array}$ & $36.2 \pm 5.5$ & $36.3 \pm 6.3$ \\
\hline Study age (d) & 16.3 (range $1-125$ day) & 22.9 (range $3-118$ day) \\
\hline Study wt (g) & $2472 \pm 896$ & $2294 \pm 930$ \\
\hline \multicolumn{3}{|l|}{ Procedure } \\
\hline $\begin{array}{l}\text { Repair of } \\
\text { tracheo- } \\
\text { esophageal } \\
\text { fistula }\end{array}$ & 4 & 2 \\
\hline $\begin{array}{l}\text { Small bowel } \\
\text { resection }\end{array}$ & 3 & 3 \\
\hline $\begin{array}{l}\text { Large bowel } \\
\text { resection }\end{array}$ & 0 & 1 \\
\hline $\begin{array}{l}\text { Repair of om- } \\
\text { phalocele }\end{array}$ & 2 & 0 \\
\hline Other & 2 & 1 \\
\hline
\end{tabular}

Values are mean $\pm \mathrm{SD}$.

* Sternal cleft repair and ligation of patent ductus arteriosus (diet group A). Resection of liver hemangioma (diet group B).

content was determined with the aid of a dual inlet, double collector isotope-ratio mass spectrometer (Vacuum Generators, Micromass 602D, Winsford, Cheshire, England) (5). Urinary creatinine content was determined by standard automated laboratory technique.

The $15 \mathrm{~N}$-enrichment of urinary urea was calculated as previously described (5). The plateau value of $15 \mathrm{~N}$-enrichment of urea was determined by visual inspection. Calculations of whole body amino $\mathrm{N}$ flux, protein synthesis, and breakdown were calculated from the plateau values of urinary $15 \mathrm{~N}$-urea enrichment using the model of Picou and Taylor-Roberts (8). The two diet groups were compared by an unpaired Students $t$ test. Linear regression was used to compare $\mathrm{N}$ intake and retention.

Postoperatively, all the infants were clinically stable. There were no significant differences in birth weight, gestational age, study age, or study weight between the two diet groups. There was, however, a considerable range in study age in both diet groups. Those requiring surgery several months after birth were very low birth weight premature infants who required small bowel resection due to strictures arising from necrotizing enterolcolitis.

It was intended that both diet groups receive between 80 and 90 nonprotein $\mathrm{kcal} / \mathrm{kg} / \mathrm{day}$, whilst diet group A would receive $2.5 \mathrm{~g}$ amino acid and diet group $\mathrm{B}, 4 \mathrm{~g} \mathrm{~kg} /$ day. The actual rates of infusion had to be adjusted according to the clinical tolerance of the infants. Mean nonprotein energy intakes of diet group A (75SD $17 \mathrm{kcal} / \mathrm{kg} /$ day) were less than those of diet group B (91 SD $24 \mathrm{kcal} / \mathrm{kg} /$ day), but the differences were not statistically significant. Both groups received less total amino acids (2.29 SD 0.43 and $3.89 \mathrm{SD} 0.51 \mathrm{~g} / \mathrm{kg} /$ day, respectively). than was intended, but not markedly so.

$\mathrm{N}$ intakes, balance, and apparent utilization are shown in Table 2. Diet group B received a significantly higher $N$ intake and had a correspondingly higher $\mathrm{N}$ balance. However, nitrogen utilization $(\mathrm{N}$ balance $/ \mathrm{N}$ intake $\times 100)$ did not differ between the two groups. The range of $\mathrm{N}$ intakes permitted an examination of the relationship between $\mathrm{N}$ intake and balance: $\mathrm{N}$ balance $=$ $0.928 ; \mathrm{N}$ intake $=153.2(r=0.85, p<0.01)$ (Fig. 1$)$.

Amino $N$ flux, protein synthesis, and protein breakdown (B) rates are shown in Table 3 . There were no significant differences
Table 2. $N$ intake, balance, and apparent utilization $(\text { mean } \pm S D)^{*}$

\begin{tabular}{lcc}
\hline & \multicolumn{2}{c}{ Diet group } \\
\cline { 2 - 3 } Parameter & $\mathrm{A}$ & $\mathrm{B}$ \\
\hline Intake $(\mathrm{mg} \mathrm{N} / \mathrm{kg} /$ day) & $312 \pm 63$ & $520 \pm 68$ \\
Balance $(\mathrm{mg} \mathrm{N} / \mathrm{kg} /$ day $)$ & $145 \pm 110$ & $315 \pm 93$ \\
Utilization $(\%)$ & $43.6 \pm 35.5$ & $60.0 \pm 10.9$ \\
\hline
\end{tabular}

${ }^{*} \mathrm{~N}$ intake $(p<0.001)$ and balances $(p<0.001)$ are significantly different, but the utilizations are not.

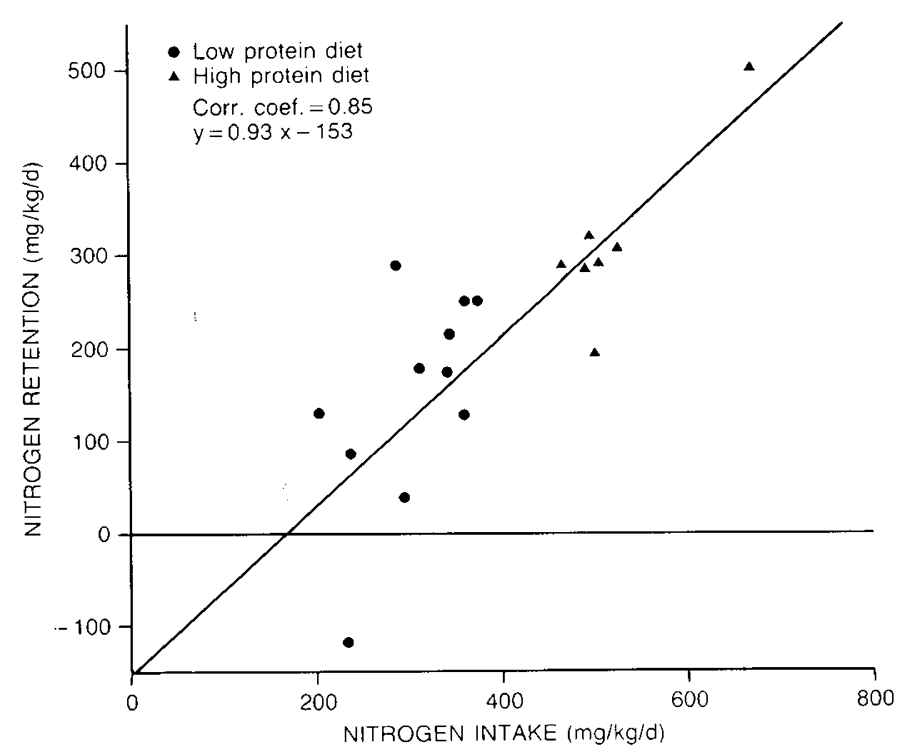

Fig. 1. The relationship of infused $\mathrm{N}$ to $\mathrm{N}$ retention.

Table 3. Rates of total body protein turnover and urinary 3methylhistidine (3MH) and creatinine excretion (mean $\pm S D$ )

\begin{tabular}{|c|c|c|}
\hline \multirow[b]{2}{*}{ Parameter } & \multicolumn{2}{|c|}{ Diet group } \\
\hline & A & B \\
\hline $\begin{array}{l}\text { Amino nitrogen flux (Q) } \\
(\mathrm{mg} \mathrm{N} / \mathrm{kg} / \mathrm{h})\end{array}$ & $74.4 \pm 37.5$ & $77.3 \pm 16.6$ \\
\hline $\begin{array}{l}\text { Protein synthesis }(\mathrm{S}) \\
(\mathrm{g} / \mathrm{kg} / \text { day })\end{array}$ & $10.12 \pm 5.81$ & $10.32 \pm 2.48$ \\
\hline $\begin{array}{l}\text { Protein breakdown (B) } \\
(\mathrm{g} / \mathrm{kg} / \text { day })\end{array}$ & $9.21 \pm 5.45$ & $8.35 \pm 2.25$ \\
\hline $\mathrm{S} / \mathrm{Q} \times 100$ & $88.8 \pm 7.6$ & $88.6 \pm 3.3$ \\
\hline $\mathrm{B} / \mathrm{Q} \times 100^{*}$ & $80.6 \pm 5.2$ & $71.2 \pm 5.2$ \\
\hline $3 \mathrm{MH}(\mu \mathrm{mol} / \mathrm{kg} /$ day $)$ & $1.40 \pm 0.60$ & $2.23 \pm 1.37$ \\
\hline Creatinine $(\mathrm{mg} / \mathrm{kg} /$ day $)$ & $9.64 \pm 1.74$ & $9.98 \pm 2.40$ \\
\hline $\begin{array}{l}3 \mathrm{MH} / \mathrm{creatinine} \text { ratio } \\
(\mu \mathrm{mol} / \mathrm{mg})\end{array}$ & $0.15 \pm 0.06$ & $0.25 \pm 0.21$ \\
\hline
\end{tabular}

* Significant differences between diets in $\mathrm{B} / \mathrm{Q} \times 100(p<0.01)$, by unpaired $t$ test; $(p<0.04)$ when adjustment is made for multiple comparisons.

between the two diet groups in any of these three parameters. Net protein synthesis was significantly higher $(p<0.01)$ in diet group $B$. There were no differences between the two diet groups in the fraction of amino $\mathrm{N}$ flux utilized for protein synthesis. However, endogenous protein breakdown contributed a significantly smaller fraction of the amino $\mathrm{N}$ flux in diet group $\mathrm{B}$ compared with diet group A $(p<0.01)$.

Urinary 3-methylhistidine and creatinine excretions are shown in Table 3. Creatinine excretions were similar between the two groups. There was a wide range in urine 3-methylhistidine excretion in both diet groups and no significant difference in this parameter between the two groups. 


\section{DISCUSSION}

We have previously shown that parenterally fed very low birth weight infants receiving approximately $400 \mathrm{mg} \mathrm{N}$ from Vamin and about 80 non-protein $\mathrm{kcal} / \mathrm{kg} /$ day were able to retain $\mathrm{N}$ at intrauterine levels (6). The studies of Zlotkin et al. (10) have confirmed that these levels of amino acid and nonprotein energy intake will meet the requirements of the parenterally fed neonate. Diet group A received approximately requirement level of nonprotein energy, but only about $80 \%$ of what we would now regard to be their ideal $\mathrm{N}$ intake. There was considerable variance in $\mathrm{N}$ balance in diet group $\mathrm{A}$ and indeed, one infant was in negative balance. On the other hand, the infants in diet group B showed much smaller variance in $\mathrm{N}$ balance and their mean $\mathrm{N}$ retention $(315 \mathrm{mg} / \mathrm{kg} / \mathrm{day})$ was above intrauterine accretion rates for gestational age and weight (approximately $240 \mathrm{mg} / \mathrm{kg} /$ day) (11). Our data (Fig. 1) suggest that a $\mathrm{N}$ intake of about $450 \mathrm{mg}$ $\mathrm{N} / \mathrm{kg} /$ day) should meet the needs of a neonate in the immediate postoperative period. Conversely, the lower intake of $312 \mathrm{mg} \mathrm{N} /$ $\mathrm{kg}$ /day received by diet group A may not be sufficient to meet the needs of some infants. Zlotkin (12) has recently published data relating to the $\mathrm{N}$ requirements of full-term newborns undergoing surgery and concludes that their needs are approximately $280 \mathrm{mg} \mathrm{N} / \mathrm{kg} /$ day. It is important to note that the net $\mathrm{N}$ retention aimed at in Zlotkin's study of term infants was 190 $\mathrm{mg} \mathrm{N} / \mathrm{kg} /$ day. The infants in the present study were smaller and less mature; hence, the higher intrauterine $\mathrm{N}$ accretion rates mentioned above.

Based on earlier studies in adults $(1,3)$ and in children undergoing skin grafts (2), we had hypothesized that surgery in the neonate would result in a reduction in whole body protein synthesis and that this reduction in synthesis might be corrected by providing more exogenous "precursor" amino acids. Thus, we had expected synthesis rates to be higher in diet group B. It is possible that part of the reason for the failure to find differences was the fact that the two diet groups were not completely matched with regard to the reason for surgery. Ideally, perhaps, only one type of surgical condition should have been studied, but patient number would have made that rather impractical. It is possible that neonates requiring bowel surgery might metabolize $15 \mathrm{~N}$ glycine differently from infants requiring other forms of surgical intervention. To examine this issue, we compared the four infants in group A with tracheoesophageal fistula with the two in group $B$ with the same condition. Similarly, we compared the six babies with small bowel resection (three in each diet group). No significant differences were seen in flux, synthesis, or breakdown between the two diet groups in infants with tracheoesophageal fistula. However, among the infants requiring small bowel resection, rates of whole body amino nitrogen flux protein synthesis were marginally different ( $p<0.05$ by impaired $t$ test); protein synthesis rates for diet group A were $11.4 \mathrm{~g} / \mathrm{kg} /$ day (range 8.9$13.4 \mathrm{~g}$ ) compared with $8.4 \mathrm{~g} / \mathrm{kg} /$ day (range $5.2-10.3 \mathrm{~g}$ ) in group $B$. Given the small numbers, these differences must be interpreted with caution.

We had hoped to develop a within-subject comparison by studying the neonates about 2 wk after surgery, and while they were still on parenteral nutrition. Unfortunately, this was possible in only three of the 17 subjects, and no significant differences could be demonstrated in $\mathrm{N}$ metabolism. We therefore also compared our present results in with earlier studies. Rates of amino $\mathrm{N}$ flux, synthesis, and breakdown in the present study are all higher (approximately 18\%) than we had previously observed in very low birth weight infants (6), but not significantly so. An additional consideration is the possibility that surgery might alter glycine metabolism, since glycine is an important component of collagen. Thus, $15 \mathrm{~N}$-glycine might be an unsuitable tracer to use to study whole body $\mathrm{N}$ metabolism, at least in neonates. The available evidence is against this possibility. First, we have already noted the similarity of our present results with earlier studies in neonates on parenteral nutrition but who had not undergone surgery (6). Second, we are currently studying postsurgical neonates using both $15 \mathrm{~N}$ glycine and $13 \mathrm{C}$ leucine. Preliminary results of these studies have been reported in abstract form (13) and do not show any significant differences in the estimate of whole body amino $\mathrm{N}$ flux obtained from the two different amino acids and labels.

Our data show a strong and linear relationship between $\mathrm{N}$ intake and $\mathrm{N}$ retention (balance), that is evident $(r=0.80)$ even if the subjects with the highest and lowest $\mathrm{N}$ balance (Fig. 1) are excluded. The model used to study $\mathrm{N}$ metabolism in the present work assumes a steady state. Hence, movement into the "theoretical" amino $\mathrm{N}$ pool (i.e. diet and protein breakdown) is equal to flow out (i.e. urinary nitrogen excretion and protein synthesis). Since there were no (or negligible) stool losses in the present study, net protein synthesis is arithmetically equal to $\mathrm{N}$ balance. The enhanced $\mathrm{N}$ balance seen with increased nitrogen intake was as a result of a reduction in the fraction of amino $\mathrm{N}$ flux coming from the breakdown of endogenous protein.

O'Keefe et al. (14) have recently shown in adults that the provision of amino acid and glucose in the place of saline, postoperatively will at least partially reverse the effects of surgery on protein synthesis. Given the limited reserves of these infants and the fact that most of them underwent major surgery, we did not believe it was ethically justified to have a third diet group who received no amino acids and calories. Thus, our failure to find a reduction in protein synthesis may be due to the fact that all of our infants were receiving amino acids and energy.

The levels of creatinine excretion are similar to those we have previously observed in infants of this size (15). Similarly, the $3 \mathrm{MH}$ excretion rates are comparable to nonsurgical neonates we had previously studied (8). There appears, therefore, to be no evidence of any increase in skeletal muscle breakdown postoperatively in the infants studied.

Our data do show it is possible to achieve intrauterine rates of $\mathrm{N}$ accretion even during the 3 days immediately postsurgery. The comparison of the present results with our earlier studies in infants fed with Vamin suggests that $\mathrm{N}$ utilization is partially impaired postoperatively. We tentatively suggest then that amino $\mathrm{N}$ intake of approximately $450 \mathrm{mg} / \mathrm{kg} /$ day with a nonprotein energy intake of $85-90 \mathrm{kcal} / \mathrm{kg} /$ day will permit intrauterine $\mathrm{N}$ accretion rates even in the immediate postoperative period.

Acknowledgements. The authors thank Dr. E. Outerbridge, Director of Neonatology at The Montreal Children's Hospital for his support and encouragement; the nurses of the Neonatal Intensive Care Unit for their invaluable assistance in the conduct of the balance and turnover studies; and Dr. G. H. Anderson, Department of Nutritional Sciences, University of Toronto, for assistance in carrying out the urine 3-methylhistidine analyses.

\section{REFERENCES}

1. Crane CW, Picou D, Smith R, Waterlow JC 1977 Protein turnover in patients before and after elective orthopaedic operations. Br J Surg 64:129-133

2. Kien CL, Young VR, Rohrbaugh DK, Burke JF 1978 Whole body protein synthesis and breakdown rates in children before and after reconstructive surgery of the skin. Metabolism 27:27-34

3. O'Keef SJD, Sender PM, James WPT 1974 'Catabolic' loss of body nitrogen in response to surgery. Lancet 2:1035-1039

4. Heird WC, Driscoll JM, Schullinger JN, Grebin B, Winters RW 1972 Intravenous alimentation in pediatric patients. J Pediatr 80:351-372

5. Pencharz PB, Masson M, Desgranges F, Papageorgiou A 1981 Total body protein turnover in human premature neonates: effects of birthweight, intrauterine nutritional status and diet. Clin Sci 61:207-215

6. Duffy B, Gunn $T$, Collinge J, Pencharz P 1981 The effect of varying protein quality and energy intake on the nitrogen metabolism of parenterally fed very low birthweight $(<1600 \mathrm{~g})$ infants. Pediatr Res 15:1040-1044

7. Pencharz PB, Steffee W, Cochran W, Scrimshaw NS, Rand WM, Young VR 1977 Protein metabolism in human neonates. Clin Sci 52:485-498

8. Picou D, Taylor-Roberts T 1969 The measurement of total protein synthesis and catabolism and nitrogen turnover in infants in different nutritional states and receiving different amounts of dietary protein. Clin Sci 36:283-287

9. Muro HN, Fleck A 1969 Analysis of tissues and body fluid for nitrogenous constitutents. In: Munro HN (ed) Mammalian Protein Metabolism. Aca- 
demic Press, New York, pp 424-525

10. Zlotkin SH, Bryan MH, Anderson GH 1981 Intravenous nitrogen and energy intakes required to duplicate in utero nitrogen accretion in prematurely born infants. J Pediatr 99:115-120

11. Widdowson EM 1981 Changes in body composition during growth. In: Davies J, Dobbing J (eds) Scientific Foundations of Paediatrics, 2nd ed. Heinemann, London, pp 330-342

12. Zlotkin SH 1984 Intravenous nitrogen intake requirements in full-term newborns undergoing surgery. Pediatrics 73:493-496
13. Pencharz P, Beesley J, Canagarayar U, Van Aerde J, Renner J, Sauer P, Wesson D, Swyer P 1984 Protein metabolism of parenterally fed neonates: combined $13 \mathrm{C}$ and $15 \mathrm{~N}$ studies. Pediatr Res 18:A672

14. O'Keefe SJD, Moldawer LL, Young VR, Blackburn GL 1981 The influence of intravenous nutrition on protein dynamics following surgery. Metabolism 30:1150-1154

15. Pencharz PB, Masson M, Desgranges F, Papageorgiou A 1984 The effects of post-natal age of the whole body protein metabolism and urinary 3-methylhistidine excretion of premature infants. Nutr Res 4:9-19

\section{Announcement}

\section{Announcement of the 1986 Pediatric Endocrinology Examination}

The Subspecialty Committee of Pediatric Endocrinology of the American Board of Pediatrics will administer its next certifying examination on Friday, July 18, 1986.

The following criteria must be met to be eligible to sit for the examination: 1) certification by the American Board of Pediatrics; 2) 2 years of full-time graduate training in pediatric endocrinology; 3) verification of training and recommendation by Pediatric Endocrinology Program Director.

Each application will be considered individually and must be acceptable to the Subspecialty Committee of Pediatric Endocrinology.

Registration for this examination will extend from October 1, 1985, until January 31, 1986. To request an application, please contact the Board office at the address listed below.

The application fee for the written examination is $\$ 635$ ( $\$ 235$ processing and evaluating $+\$ 400$ examination). Candidates who are not approved to take the examination will be refunded the examination fee. The processing and evaluating fee will be retained.

Please direct any inquiries to: American Board of Pediatrics, 111 Silver Cedar Court, Chapel Hill, NC 27514-1651 (919) 9290461 . 